\title{
Association of preoperative EpCAM Circulating Tumor Cells and peripheral Treg cell levels with early recurrence of hepatocellular carcinoma following radical hepatic resection
}

Yan Zhou ${ }^{2+}$, Beili Wang ${ }^{2+}$, Jiong Wu ${ }^{2}$, Chunyan Zhang ${ }^{2}$, Yiwen Zhou ${ }^{2}$, XinRong Yang ${ }^{1}$, Jian Zhou' ${ }^{1}$, Wei Guo ${ }^{2 *}$ and Jia Fan ${ }^{1 *}$

\begin{abstract}
Background: This study was carried out to determine the prognostic significance of preoperative peripheral epithelial cell adhesion molecule- positive $\left(E p C A M^{+}\right)$circulating tumor cell (CTC) and T regulatory (Treg) cell levels in hepatocellular carcinoma (HCC) patients for the prediction of postoperative recurrence following curative resection.

Methods: A total of 49 patients about to undergo curative resection for HCC were recruited into the study. PCR and FACS were used to detect the preoperative levels of EpCAM ${ }^{\text {mRNA+ }} \mathrm{CTCS}$ and $C D 4^{+} \mathrm{CD} 25^{+} \mathrm{Foxp} 3^{+}$Treg cells. The prognostic value of EpCAM ${ }^{\text {mRNA+ }} \mathrm{CTCS}, \mathrm{CD}^{+} \mathrm{CD} 25^{+} \mathrm{Foxp}^{+}$Treg cells, and other clinicopathological factors were analyzed by applying the Kaplan-Meier method and the multivariate Cox proportional hazards model.

Results: The number of EpCAM ${ }^{\mathrm{mRNA}+} \mathrm{CTCS}$ and Treg/CD4 $4^{+}$cells showed significant correlation as prognostic factors of postoperative HCC recurrence: EpCAM ${ }^{\mathrm{mRNA}+} C T C \geq 2.22(P=0.001)$ and Treg/CD4 $4^{+} \geq 5.07(P=0.045)$, with EpCAM ${ }^{\text {mRNA+ }} C T C \geq 2.22(P=0.003, H R=6.668)$ being the most important indicator. Patients with high CTC/ Treg levels showed a significantly higher risk of developing postoperative HCC recurrence than those with low CTC/Treg levels ( $66.7 \%$ vs. $10.3 \%, P<0.001)$. The high CTC/low Treg group also presented higher 1-year recurrence rates compared with the low CTC/low Treg level group ( $50.0 \%$ vs. $10.3 \%, P=0.004)$.

Conclusions: Elevated EpCAM ${ }^{\text {mRNA+ }} \mathrm{CTC}$ and Treg/CD4 $4^{+}$levels were associated with early recurrence of HCC, indicative of poor clinical outcome. The combined detection of EpCAM ${ }^{\mathrm{mRNA}+} \mathrm{CTC}$ and $\mathrm{Treg} / \mathrm{CD} 4^{+}$may therefore provide a novel prognostic predictor for HCC patients.
\end{abstract}

Keywords: Hepatocellular carcinoma, Tumor recurrence, Circulating tumor cells, Epithelial cell adhesion molecule, Regulatory T cells

\footnotetext{
*Correspondence: guo.wei@zs-hospital.sh.cn; fan.jia@zs-hospital.sh.cn

†Equal contributors

${ }^{2}$ Department of Laboratory Medicine, Zhongshan Hospital, Fudan University,

136 Yi Xue Yuan Road, Shanghai 200032, People's Republic of China

'Liver Cancer Institute, Fudan University, 136 Yi Xue Yuan Road, Shanghai

200032, People's Republic of China
} 


\section{Background}

Hepatocellular carcinoma (HCC) is the fifth most common malignancy worldwide, and is ranked second in global cancer-related mortality. The high incidence and poor prognosis of $\mathrm{HCC}$ are current focuses of clinical research [1]. The main treatments for HCC include surgical resection and liver transplantation. However, the tumor recurrence rate exceeds $70 \%$ after 5 years following resection, and recurrence is considered the main contributor to mortality [2]. Imaging tests and pathological examination are limited in terms of accuracy and sensitivity, while common serum markers display poor diagnostic performance [3]. It is therefore critical to find robust prognostic biomarkers with which to monitor postoperative recurrence for HCC patients [4].

The progression of a tumor consists of two stages: growth of the primary tumor and development of distant metastases. Circulating tumor cells (CTCs) spread from the primary tumor sites or the metastases into the peripheral blood supply, and possess characteristics of stem cells combined with invasive ability. Distant metastases induced by CTC invasion are believed to be responsible for the majority cases of recurrence and cancer-related deaths. Therefore, isolation and detection of CTCs will help us to understand the processes of early metastasis and recurrence, and the aggressiveness of tumors [5].

Epithelial cell adhesion molecule-positive $\left(\mathrm{EpCAM}^{+}\right)$ CTCs are a proven independent risk factor for HCC recurrence in our previous study [6], while immune suppressive $\mathrm{CD} 4{ }^{+} \mathrm{CD} 25^{+}$regulatory $\mathrm{T}$ cells (Treg) intranuclear expressing Foxp $3^{+}$are associated with tumor immune tolerance and immune escape [7]. Treg cell proliferation is known to be significantly associated with tumor invasion and poor prognosis [7], and increased proportions of Foxp $3^{+}$Treg cells were shown to be an important predictor for the high recurrence and poor survival rates of $\mathrm{HCC}$ patients [8].

The prognostic significance of CTC or Treg cells alone for HCC recurrence has therefore already been investigated; however, the prognostic value of CTCs in combination with Tregs has not yet been established. The objective of our study was therefore to determine the prognostic significance of preoperative $\mathrm{EpCAM}^{+} \mathrm{CTCs}$ and Treg cells population levels for recurrence in HCC patients following curative resection, and to explore the interaction between $\mathrm{EpCAM}^{+} \mathrm{CTCs}$ and the tumor immune microenvironment.

\section{Methods}

\section{Patients}

From March to June 2012, 49 HCC patients undergoing curative resection at the Zhongshan Hospital were recruited (36 males and 13 females), with a median age of
50 years (range: 37 to 83). According to Child-Pugh score criteria, 48 patients were classified as grade A, and one as grade B. All cases enrolled had to fulfill the following criteria: (i) Hepatitis B virus-related HCC with pathological diagnosis; (ii) about to receive curative resection; (iii) no history of blood transfusion, acquired immunologically mediated disease or any anti-tumor treatment within the preceding 6 months. This study adopted the Barcelona Clinic Liver Cancer (BCLC) staging system and the Edmondson-Steiner grading system. Fifty healthy volunteers were recruited as the control group (35 males and 15 females). All patients provided informed consent before sample collection.

Approval for the use of human subjects was obtained from the Research Ethics Committee of Zhongshan Hospital, and informed consent was obtained from each individual enrolled in this study.

\section{Specimen collection}

A peripheral blood sample $(6 \mathrm{~mL}$ each) was collected into an EDTA-K2 anticoagulant tube (BD Biosciences, USA in the morning on the day of surgery before the operation. Prior to this, the first $6 \mathrm{~mL}$ of blood was discarded to avoid epithelial cell contamination. RNA extraction and reverse transcription were completed within $8 \mathrm{~h}$ following collection (details below). Samples of cDNA were preserved at $-20{ }^{\circ} \mathrm{C}$. All the patients received curative resection and the common operation time was about $2-3 \mathrm{~h}$ and the average bleeding was $300 \mathrm{ml}$.

\section{Apparatus and reagents}

The monocyte isolation kit used was Ficoll-Paque Plus (GE Healthcare, USA). CD45 cells were isolated with RosetteSep Human CD45 Depletion Cocktail (Stemcell Technologies, Canada). Other equipment used included the RNA extraction kit, RNeasy Mini Kit (Qiagen, Germany), the QuantiTect Reverse Transcription kit, the Human Regulatory $\mathrm{T}$ cell Staining Kit (eBioscience, USA), the LightCycler 480 Real-time PCR system (Roche, Switzerland) and the FACS Calibur flow cytometry system (BD Biosciences, USA).

\section{EpCAM ${ }^{\text {mRNA+ }}$ CTC detection and qRT-PCR}

CTC detection was processed by a negative enrichment and quantitative real time polymerase chain reaction (qRT-PCR) based platform [9]. A peripheral blood sample was collected for each patient $(5 \mathrm{ml})$. Target cells were first negative enriched by RosetteSep Human CD45 Depletion Cocktail (StemCell, Canada), which to remove leukocyte impureness [9]. After enrichment, messenger RNA (mRNA) was extracted from the target cells with an RNeasy Mini 
Kit and then reverse transcribed into cDNA using the QuantiTect Reverse Transcri EpCAM ption kit. All protocols were according to manufacturer's instructions. qRT-PCR analysis of and $\beta$-actin (as an internal control) transcripts were performed using the Light Cycler 480 platform (Roche Diagnostics, Germany) with fluorescent Taqman methodology. PCR reactions were performed using the following conditions: $2 \mathrm{~min}$ at $50{ }^{\circ} \mathrm{C}$ and $2 \mathrm{~min}$ at $95{ }^{\circ} \mathrm{C}$, followed by 45 cycles at $95{ }^{\circ} \mathrm{C}$ for $30 \mathrm{~s}$ and $60{ }^{\circ} \mathrm{C}$ for $30 \mathrm{~s}$. Florescent detection was performed at $60{ }^{\circ} \mathrm{C}$, and three replicates were carried out for each sample. Invitrogen (nvitrogen, USA) synthesized the primers and probe segments. The forward primer :5'CTCGCGTTCGGGCTTCT-3', the reverse primer: 5'- TGTAGTTTTCACAGACACATTCTTCCT-3', and the probe [6FAM] ACGGCGACTTTTGCCGCAGCT TA-MRA were used for analysis of EpCAM expression. The forward primer: 5' -TGGCATTGCCGACAGGAT-3', the reverse primer: 5'-CTCAGGAGGAGCAATGAT CTTGAT-3', and the probe [6FAM] -ATCACTG CCCTGGCACCCAGCATA-MRA were used for analysis of $\beta$-actin expression. All primers and probes were designed and synthesized by the Life Technology Corporation (Invitrogen, USA).

Gene expression levels were calculated with the following equations:

$$
2^{-\Delta \Delta C \mathrm{~T}}[\Delta \mathrm{CT}=\mathrm{Ct}(\mathrm{EpCAM})-\mathrm{Ct}(\beta \text {-actin }) \text {, and }
$$$$
\Delta \Delta \mathrm{CT}=\Delta \mathrm{CT}-\mathrm{Ct} \text { (calibrator), }
$$

where $\mathrm{Ct}$ (calibrator) stands for the mean $\Delta \mathrm{CT}$ of the 50 healthy volunteers $[9,10]$.

\section{Detection of lymphocyte subgroups}

Two sets of four-color florescent antibody, CD3/ CD8/CD45/CD4 (BD Biosciences) and CD3/CD16 ${ }^{+}$ CD56/CD45/CD19 (BD Biosciences), were added (20 $\mu \mathrm{l}$ each) into two separate flow cytometry tubes. The sample (50 $\mu \mathrm{l}$ whole blood each) was added to each tube, followed by incubation at room temperature (RT) under darkness for $15 \mathrm{~min}$. After adding $0.45 \mathrm{ml}$ erythrocytolysin (BD Biosciences), the solution was incubated for another $10 \mathrm{~min}$. The solution was then centrifuged for $5 \mathrm{~min}$ at $1200 \mathrm{rpm}$. The supernatant was discarded and the pellet was washed twice with $2 \mathrm{ml}$ PBS. After resuspension in $0.4 \mathrm{ml}$ phosphate-buffered saline (PBS), the sample was loaded for flow cytometry analysis. Data analyses were performed with MultiSET software (BD Biosciences). Measurements included percentages of B cells $\left(\mathrm{CD} 19^{+}\right)$, $\mathrm{T}$ cells $\left(\mathrm{CD}^{+}\right), \mathrm{CD} 4^{+} \mathrm{T}$ cells, $\mathrm{CD} 8^{+} \mathrm{T}$ cells and NK cells $\left(\mathrm{CD} 16^{+} \mathrm{CD} 56^{+}\right)$and the ratio of $\mathrm{CD}^{+} / \mathrm{CD}^{+} \mathrm{T}$ cells.

\section{Detection of $\mathrm{CD}^{+} \mathrm{CD} 25^{+} \mathrm{Foxp}^{+}$Tregs}

After the addition of $20 \mu \mathrm{l}$ anti-CD4-FITC/antiCD25-APC (eBioscience) and the relevant isotype control antibody (IgG1 -FITC and IgG1 -APC, respectively; eBioscience) into two separate flow cytometry tubes, $100 \mu \mathrm{L}$ whole blood sample was added, followed by incubation at $4{ }^{\circ} \mathrm{C}$ for $30 \mathrm{~min}$ in darkness. After the erythrocytolysis step (as above), each tube was supplemented with $1 \mathrm{ml}$ permeabilization reagent and incubated at $4{ }^{\circ} \mathrm{C}$ for $60 \mathrm{~min}$. After washing with PBS, $100 \mu \mathrm{l}$ mouse serum was added to the solution and the mixture was incubated at RT under darkness for $15 \mathrm{~min}$. Intracellular antibody $20 \mu \mathrm{l}$ anti-Foxp3-PE, and isotype control IgG2a-K-PE (both from eBioscience), were each added, and the resulting solution was incubated at RT under darkness for another $30 \mathrm{~min}$. After resuspension in PBS, the sample was loaded for flow cytometry analysis. Measurements included proportions of $\mathrm{CD} 4{ }^{+} \mathrm{CD} 25^{+}$ Foxp $3^{+} \mathrm{T}$ cells (Tregs) in total lymphocytes, $\mathrm{CD}^{+} \mathrm{T}$ cells, $\mathrm{CD} 4^{+} \mathrm{T}$ cells and $\mathrm{CD}^{+} \mathrm{T}$ cells.

\section{Follow-up for HCC recurrence}

All patients had postoperative follow-ups [11]. Time to recurrence (TTR) was defined as the period from curative excision to diagnosis of HCC recurrence (including intrahepatic recurrence and extrahepatic metastasis) based on MRI and serum AFP levels [12, 13]. Early recurrence was defined as recurrence within 12 months following excision [14].

\section{Statistical analysis}

Prognostic cut-off values were determined using Xtile 3.6.1 software [15]. All statistical analyses were performed using SPSS 17.0. Categorical data and measurement data were assessed with the $X^{2}$ test and the $t$-test, respectively. Prognostic factors for early recurrence were evaluated with univariate analysis and multivariate COX regression analysis. The associations between TTR and the prognostic factors were assessed with Kaplan-Meier survival analysis, and the inter-curve differences were assessed with the logrank test. $\mathrm{P}$ values $<0.05$ were considered statistically significant.

\section{Results}

\section{Patient characteristics}

The characteristics of the study participants were listed in Additional file 1: Table S1. The cohorts were well matched for serum AFP, age, and sex overall. There were 44. (89.8\%) patients with early HCC (BCLC $0-\mathrm{A})$ and 14 (28.6\%) patients with early recurrence. Majority of patients had Child-Pugh score A with multiple tumor. 
EpCAM ${ }^{\mathrm{mRNA}+}$ CTCs and Treg/CD4 ${ }^{+}$cells definition

According to previous studies, the prognostic cut-off value for $\mathrm{HCC}$ recurrence of $E p C A M^{\mathrm{mRNA}+} \mathrm{CTCs}\left(2^{-\Delta \Delta C \mathrm{~T}}\right)$ was 2.0 [9]. In our study, the optimal prognostic cut-off values calculated by X-tile 3.6.1 software for EpCAM mRNA+ CTCs $\left(2^{-\triangle \Delta C T}\right)$ and Treg/CD4 $4^{+}(\%)$ were 2.22 and 5.07, respectively. The original data of flow cytometry analysis for Tregs was shown in Additional file 2: Figure S1.

\section{Association of clinical characteristics and pathological factors with early recurrence}

EpCAM ${ }^{\text {mRNA+ }}$ CTC $\left(P<0.001\right.$; Fig. 1a) and Treg/CD $4{ }^{+}$ ratio $(P=0.02$; Fig. 1a, Additional file 3 : Table $S 2)$ was observed to be significantly higher in the postoperative recurrence in recurrence group (Table 1). In addition, Satellite lesion showed inverse correlation with early recurrence. There was a positive association between vascular invasion and early recurrence in $\mathrm{HCC}$ patients (Table 1).

Association of EpCAM ${ }^{\mathrm{mRNA}+} \mathrm{CTCs}$ and Treg/CD4 $4^{+}$ cells with clinical characteristics.

Clinical characteristics and associations with EpCAM mRNA+ CTCs and Treg/CD4 ${ }^{+}$were analyzed using the $\mathrm{X}^{2}$ test and the $t$-test for two subgroups of HCC patients according to the calculated cut-off values (Tables 2 and 3 ). Treg/CD4 $4^{+}$ratio was elevated in the EpCAM mRNA+ $C T C \geq 2.22$ group $(P=$ 0.026 ; Table 4, Fig. 2). A rising rate of vascular invasion within the EpCAM mRNA+ $C T C \geq 2.22$ group was also confirmed $(P=0.027$, Table 2$)$. Patients within the Treg/CD $4^{+} \geq 5.07 \%$ group were more likely to be younger (age $\leq 50$ years old; $P=0.040$ ) and male $(P=0.046$, Table 3$)$, and displayed an increased number of multiple satellite focuses in pathological specimens $(P=0.011$, Table 3$)$.

\section{Prognostic model for $\mathrm{HCC}$ recurrence}

Prognostic models for $\mathrm{HCC}$ recurrence were determined with univariate analysis and multivariate Cox analysis. Univariate analysis revealed significant prognostic factors for early recurrence in the $49 \mathrm{HCC}$ patient cohort, including EpCAM mRNA+ $C T C \geq 2.22(P=0.001)$, Treg/ $\mathrm{CD}^{+} \geq 5.07(P=0.045)$, and satellite lesions $(P=0.004)$. Moreover, multivariate Cox analysis revealed that EpCAM mRNA+ $\mathrm{CTC} \geq 2.22(P=0.003, \mathrm{HR}=6.668$, Table 5) and satellite lesions $(P=0.019, \mathrm{HR}=5.917$, Table 5$)$ were dependent prognostic factors. Of these three factors, $E p C A M^{\text {mRNA+ }}$ CTC $\geq 2.22$ was determined to be the key prognostic factor (Table 5 ).

\section{Survival analysis}

The 1-year recurrence rates were $12.5 \%$ and $58.8 \%$ in the $E p C A M^{\text {mRNA+ }} \mathrm{CTC}<2.22$ group and EpCAM mRNA+ CTC $\geq 2.22$ group, respectively $(P=0.002$; Fig. $3 a)$; and similarly $22.5 \%$ and $55.6 \%$ in the Treg/CD4 ${ }^{+}<5.07$ group and Treg/CD $4^{+} \geq 5.07$ group, respectively $(P=0.002$; Fig. 3b). Patients were categorized into four groups according to their combined levels of EpCAM mRNA+ CTC and Treg/CD4 ${ }^{+}$: $\mathrm{HH}$ group (high CTC and high Treg levels), HL group (high CTC and low Treg levels), LH group (low CTC and high Treg levels) and LL group (low CTC and low Treg levels). There was a statistically significant difference between the 1-year recurrence rates in the $\mathrm{HH}$ group and the LL group (66.7 \% vs.10.3 \%, $P<0.001$; Fig. 3c). The recurrence rate in the HL group was $46.4 \%$ higher than in the LL group (50.0 \% vs. $10.3 \%, P=0.004$; Fig. 3c).

\section{Discussion}

Currently, although surgical resection has greatly improved survival rates among $\mathrm{HCC}$ patients, HCC

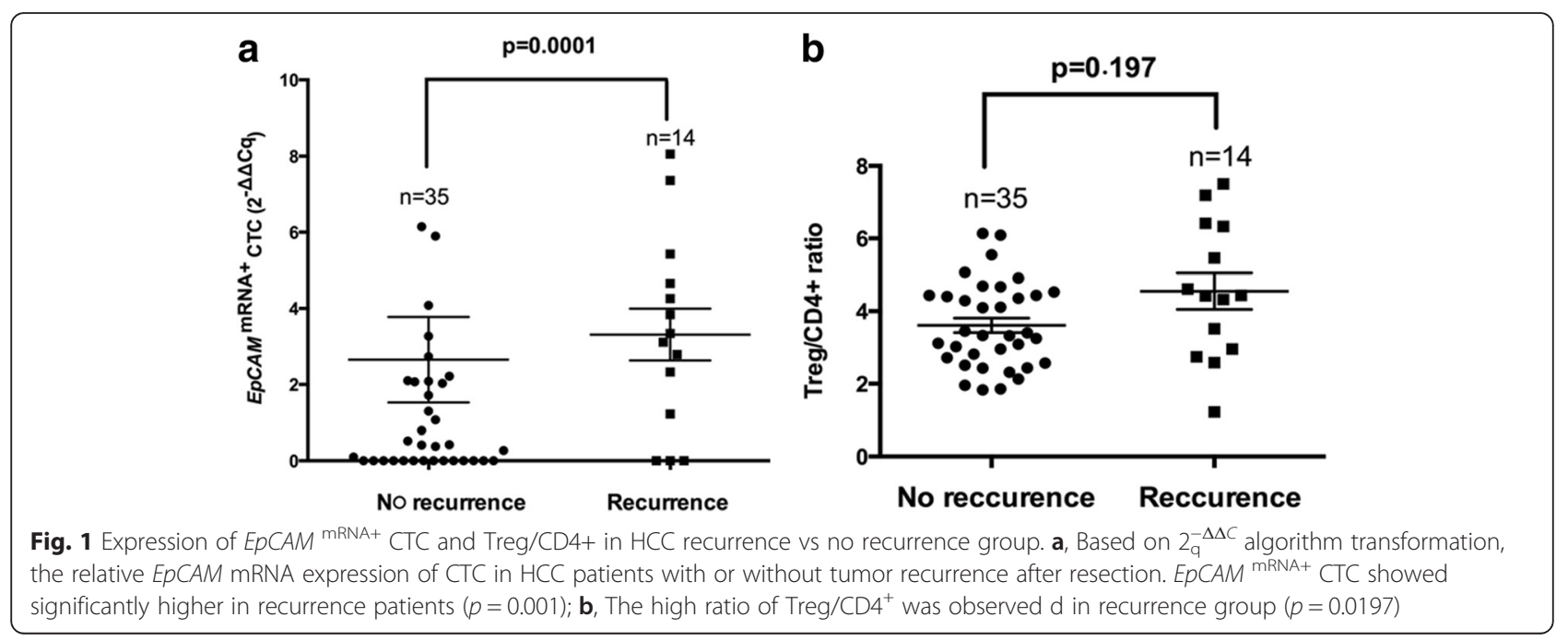


Table 1 Association of clinical characteristics and pathological factors with early recurrence

\begin{tabular}{|c|c|c|c|c|}
\hline \multirow[t]{2}{*}{ Variables } & & \multicolumn{2}{|c|}{ Early recurrence } & \multirow[t]{2}{*}{$P$} \\
\hline & & No & Yes & \\
\hline \multirow[t]{2}{*}{$\overline{\text { Age }}$} & $\leq 50$ & 15 & 8 & 0.365 \\
\hline & $>50$ & 20 & 6 & \\
\hline \multirow[t]{2}{*}{ Sex } & male & 26 & 10 & 0.838 \\
\hline & female & 9 & 4 & \\
\hline \multirow[t]{2}{*}{$\mathrm{HBsAg}$} & Negative & 7 & 2 & 0.641 \\
\hline & Postive & 28 & 12 & \\
\hline \multirow[t]{2}{*}{ HBeAg } & Negative & 27 & 9 & 0.357 \\
\hline & Postive & 8 & 5 & \\
\hline \multirow[t]{2}{*}{ HBVDNA } & $<5^{*} 10^{2}$ & 21 & 10 & 0.453 \\
\hline & $>5^{*} 10^{2}$ & 14 & 4 & \\
\hline \multirow[t]{2}{*}{$\mathrm{ALT}(\mathrm{U} / \mathrm{L})$} & $\leq 40$ & 30 & 9 & 0.412 \\
\hline & $>40$ & 5 & 5 & \\
\hline \multirow[t]{2}{*}{ AFP (ng/ml) } & $\leq 400$ & 23 & 10 & 0.768 \\
\hline & $>400$ & 12 & 4 & \\
\hline \multirow[t]{2}{*}{ EpCAM ${ }^{\text {mRNA+ }}$ CTC $(2-\Delta \Delta C q)$} & Low (<2.22) & 28 & 4 & $<0.001 *$ \\
\hline & High ( $\geq 2.22)$ & 7 & 10 & \\
\hline \multirow[t]{2}{*}{ Treg/CD4+ (\%) } & $<5.07$ & 31 & 9 & $0.020^{*}$ \\
\hline & $\geq 5.07$ & 4 & 5 & \\
\hline \multirow[t]{2}{*}{ Child-Pugh stage } & A & 34 & 14 & 0.523 \\
\hline & B & 1 & 0 & \\
\hline \multirow[t]{2}{*}{ Liver cirrhosis } & No & 9 & 3 & 0.753 \\
\hline & Yes & 26 & 11 & \\
\hline \multirow[t]{2}{*}{ Tumor number } & Single & 33 & 11 & 0.101 \\
\hline & Multiple & 2 & 3 & \\
\hline \multirow[t]{2}{*}{ Tumor size $(\mathrm{cm})$} & $\leq 5$ & 21 & 8 & 0.854 \\
\hline & $>5$ & 14 & 6 & \\
\hline \multirow[t]{2}{*}{ Tumor encapsulation } & Complete & 16 & 5 & 0.523 \\
\hline & None & 19 & 9 & \\
\hline \multirow[t]{2}{*}{ Satellite lesion } & No & 34 & 10 & $0.007^{*}$ \\
\hline & Yes & 1 & 4 & \\
\hline \multirow[t]{2}{*}{ Vascular invasion } & No & 21 & 4 & $0.047^{*}$ \\
\hline & Yes & 14 & 10 & \\
\hline \multirow[t]{2}{*}{ Edmondson stage } & $|-| \mid$ & 22 & 9 & 0.925 \\
\hline & II-IV & 13 & 5 & \\
\hline \multirow[t]{2}{*}{ BCLC stage } & $0+A$ & 33 & 11 & 0.101 \\
\hline & $B+C$ & 2 & 3 & \\
\hline
\end{tabular}

remains one of the leading causes of malignancy-related mortality worldwide with a prognosis that is still far from satisfactory, mainly due to increasing postoperative recurrence [16]. At present, predictions of
Table 2 Association of EpCAM ${ }^{+}$CTCs with clinical characteristics

\begin{tabular}{|c|c|c|c|c|}
\hline \multirow[t]{2}{*}{ Clinical characteristics } & & \multicolumn{2}{|l|}{ CTC $\left(2^{-\Delta \Delta C q}\right)$} & \multirow[t]{2}{*}{$P$} \\
\hline & & Low $(<2.22)$ & High $(\geq 2.22)$ & \\
\hline \multirow[t]{2}{*}{ Age (y) } & $\leq 50$ & 13 & 10 & 0.224 \\
\hline & $>50$ & 19 & 7 & \\
\hline \multirow[t]{2}{*}{ Sex } & Female & 9 & 4 & 0.729 \\
\hline & Male & 23 & 13 & \\
\hline \multirow[t]{2}{*}{$\mathrm{HBsAg}$} & Negative & 7 & 2 & 0.384 \\
\hline & Postive & 25 & 15 & \\
\hline \multirow[t]{2}{*}{$\mathrm{HBeAg}$} & Negative & 24 & 12 & 0.586 \\
\hline & Postive & 8 & 5 & \\
\hline \multirow[t]{2}{*}{ HBVDNA } & $<5^{*} 10^{2}$ & 21 & 10 & 0.703 \\
\hline & $>5^{*} 10^{2}$ & 11 & 7 & \\
\hline \multirow[t]{2}{*}{ Child-Pugh score } & A & 32 & 16 & 0.166 \\
\hline & B & 0 & 1 & \\
\hline \multirow[t]{2}{*}{ Liver cirrhosis } & No & 8 & 4 & 0.909 \\
\hline & Yes & 24 & 13 & \\
\hline \multirow[t]{2}{*}{$\mathrm{ALT}(\mathrm{U} / \mathrm{L})$} & $\leq 40$ & 19 & 14 & 0.103 \\
\hline & $>40$ & 13 & 3 & \\
\hline \multirow[t]{2}{*}{$\operatorname{AFP}(\mathrm{ng} / \mathrm{ml})$} & $\leq 400$ & 28 & 11 & 0.060 \\
\hline & $>400$ & 4 & 6 & \\
\hline \multirow[t]{2}{*}{ Tumor number } & Single & 30 & 4 & 0.210 \\
\hline & Multiple & 2 & 3 & \\
\hline \multirow[t]{2}{*}{ Tumor size (cm) } & $\leq 5$ & 18 & 11 & 0.566 \\
\hline & $>5$ & 14 & 6 & \\
\hline \multirow[t]{2}{*}{ Tumor encapsulation } & Complete & 15 & 6 & 0.436 \\
\hline & None & 17 & 11 & \\
\hline \multirow[t]{2}{*}{ Satellite lesion } & No & 30 & 4 & 0.210 \\
\hline & Yes & 2 & 3 & \\
\hline \multirow[t]{2}{*}{ Vascular invasion } & No & 20 & 5 & $0.027^{*}$ \\
\hline & Yes & 12 & 12 & \\
\hline \multirow[t]{2}{*}{ Edmondson stage } & $|-| \mid$ & 20 & 11 & 0.879 \\
\hline & $\|-I V$ & 12 & 6 & \\
\hline \multirow[t]{2}{*}{$\mathrm{BCLC}$ stage } & $0+A$ & 30 & 14 & 0.210 \\
\hline & $B+C$ & 2 & 3 & \\
\hline \multirow[t]{2}{*}{ Treg/CD4 ${ }^{+}(\%)$} & $<5.07$ & 29 & 11 & $0.026^{*}$ \\
\hline & $\geq 5.07$ & 3 & 6 & \\
\hline \multirow[t]{2}{*}{ Early recurrence } & No & 28 & 7 & $0.001 *$ \\
\hline & Yes & 4 & 10 & \\
\hline
\end{tabular}

$p$ value of $<0.05$ was considered statistically-significant

recurrence are mainly based on imaging or biomarkers, which have limits to reflect the dynamic changes in tumor microenvironment. It was reported that predictions of recurrence and metastasis of HCC are influenced by characteristics of both tumor cells and the tumor immune microenvironment [17]. In our previous 
Table 3 Association of Treg/CD4 ${ }^{+}$with clinical characteristics

\begin{tabular}{|c|c|c|c|c|}
\hline Clinical characteristics & & $\begin{array}{l}\text { Treg/CD4 }{ }^{+} \\
<5.07 \%\end{array}$ & $\begin{array}{l}\text { Treg/CD4 } \geq \\
5.07 \%\end{array}$ & $P$ \\
\hline \multirow[t]{2}{*}{$\overline{\text { Age }(y)}$} & $\leq 50$ & 16 & 7 & $0.040^{*}$ \\
\hline & $>50$ & 24 & 2 & \\
\hline \multirow[t]{2}{*}{ Sex } & Male & 13 & 0 & $0.046^{*}$ \\
\hline & Female & 27 & 9 & \\
\hline \multirow[t]{2}{*}{$\mathrm{HBsAg}$} & Negative & 8 & 1 & 0.534 \\
\hline & Postive & 32 & 8 & \\
\hline \multirow[t]{2}{*}{$\mathrm{HBeAg}$} & Negative & 30 & 6 & 0.609 \\
\hline & Postive & 10 & 3 & \\
\hline \multirow[t]{2}{*}{ HBVDNA } & $<5^{*} 10^{2}$ & 25 & 6 & 0.815 \\
\hline & $>5^{*} 10^{2}$ & 15 & 3 & \\
\hline \multirow[t]{2}{*}{ Child-Pugh score } & A & 39 & 9 & 0.632 \\
\hline & B & 1 & 0 & \\
\hline \multirow[t]{2}{*}{ Liver cirrhosis } & No & 10 & 2 & 0.861 \\
\hline & Yes & 30 & 7 & \\
\hline \multirow[t]{2}{*}{$\operatorname{ALT}(\mathrm{U} / \mathrm{L})$} & $\leq 75$ & 26 & 7 & 0.460 \\
\hline & $>75$ & 14 & 2 & \\
\hline \multirow[t]{2}{*}{$\operatorname{AFP}(\mathrm{ng} / \mathrm{ml})$} & $\leq 400$ & 32 & 7 & 0.881 \\
\hline & $>400$ & 8 & 2 & \\
\hline \multirow[t]{2}{*}{ Tumor number } & Single & 36 & 8 & 0.921 \\
\hline & Multiple & 4 & 1 & \\
\hline \multirow[t]{2}{*}{ Tumor size (cm) } & $\leq 5$ & 25 & 4 & 0.319 \\
\hline & $>5$ & 15 & 5 & \\
\hline \multirow[t]{2}{*}{ Tumor encapsulation } & Complete & 17 & 4 & 0.915 \\
\hline & None & 23 & 5 & \\
\hline \multirow[t]{2}{*}{ Satellite lesion } & No & 38 & 6 & $0.011 *$ \\
\hline & Yes & 2 & 3 & \\
\hline \multirow[t]{2}{*}{ Vascular invasion } & No & 22 & 3 & 0.240 \\
\hline & Yes & 18 & 6 & \\
\hline \multirow[t]{2}{*}{ Edmondson stage } & $|-| \mid$ & 25 & 6 & 0.815 \\
\hline & II-IV & 15 & 3 & \\
\hline \multirow[t]{2}{*}{ BCLC stage } & $0+A$ & 37 & 7 & 0.187 \\
\hline & $B+C$ & 3 & 2 & \\
\hline
\end{tabular}

$p$ value of $<0.05$ was considered statistically-significant

studies, molecular markers expressed on circulating tumor cells were found to be closely associated with early diagnosis and early recurrence of HCC [18]. Moreover, $\mathrm{CD} 4^{+} \mathrm{CD} 25^{+}$Foxp $3^{+}$Tregs are considered as suppressors in immune surveillance and anti-tumor

Table 4 Association between EpCAM ${ }^{+} \mathrm{CTC}$ and Treg/CD4 ${ }^{+}$

\begin{tabular}{lllll}
\hline & & \multicolumn{2}{l}{ EpCAM mRNA + CTC $(2-\Delta \Delta C T)$} & $P$ \\
\cline { 3 - 4 } & & Low $(<2.22)$ & High $(\geq 2.22)$ & \\
\hline Treg/CD4 $^{+}(\%)$ & $<5.07$ & 29 & 11 & $\mathbf{0 . 0 2 6 *}$ \\
& $>5.07$ & 3 & 6 & \\
\hline
\end{tabular}

$p$ value of $<0.05$ was considered statistically-significant

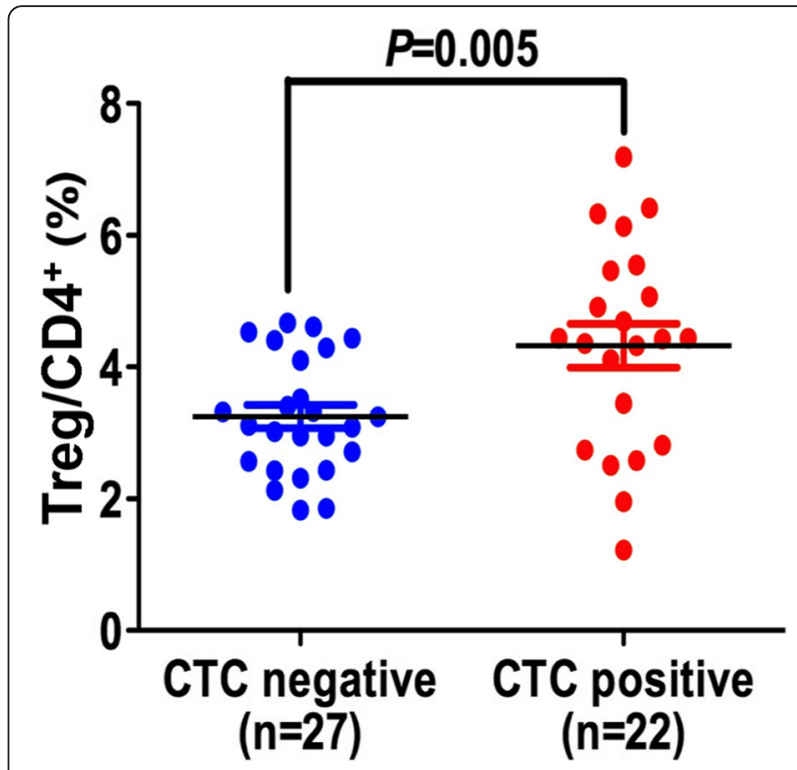

Fig. 2 Association between $\mathrm{EpCAM}^{+} \mathrm{CTC}$ and Treg/CD4 ${ }^{+}$ratio. Distribution of Treg/CD4 $4^{+}$ratio in EpCAM ${ }^{m R N A+}$-positive and negative group. The cutoff to discriminate between CTC-positive and -negative was set at 2.0 [9]

immunity, which are also proved associated with HCC invasiveness [19]. However, no previous publications have evaluated prognostic performance of circulating tumor cells and $\mathrm{CD} 4^{+} \mathrm{CD} 25^{+}$Foxp $3^{+}$Tregs. Here we first detected the combined effect of circulating tumor cells and its immune environment on hepatocellular carcinoma.

Based on the optimal prognostic cut-off values for EpCAM mRNA+ CTC $(2-\Delta \Delta C T)$ of 2.22, and Treg/ CD4+ (\%) of 5.07, as calculated using X-tile software, we found that the recurrence rate was elevated in the EpCAM mRNA+ CTC $(2-\Delta \Delta C \mathrm{~T}) \geq 2.22$ group $(P=0.001)$ and the Treg/CD4+ $(\%) \geq 5.07$ group $(P=$ $0.0029)$. The vascular invasion rate was also significantly higher in the $E p C A M^{\text {mRNA+ }} C T C \geq 2.22$ group $(P=0.027)$, suggesting the occurrence of tumor microenvironmental changes in early recurrent cases in addition to pathological changes.

With the expansion of the tumor microenvironment, tumor cells spread from the primary lesions, thereby forming circulating tumor cells (CTCs). Thousands of CTCs are generated each day, but not all CTCs can become "seeds" of metastatic recurrence. Besides environmental factors, the inherent characteristics of CTCs are also crucial for metastasis [20]. In recent years, with the introduction of the "tumor stem cell" concept, tumor stem cells have been shown to exhibit stem cell-like features including high capacity for self-renewal, differentiation, and the generation of heterogeneous cells, as well as high resistance to chemotherapy, radiotherapy and cytotoxic agents, combined with high capacity for 
Table 5 Analyses of risk factors for HCC recurrence

\begin{tabular}{|c|c|c|c|c|}
\hline & Univariate analysis & & Multivariate analysis & \\
\hline & $\mathrm{HR}(95 \% \mathrm{Cl})$ & $P$ & $\mathrm{HR}(95 \% \mathrm{Cl})$ & $P$ \\
\hline Age (>50y vs. $\leq 50 y)$ & $0.626(0.217-1.804)$ & 0.385 & N.A. & \\
\hline Gender (Male vs. Female) & $0.886(0.278-2.827)$ & 0.838 & N.A. & \\
\hline HBsAg (Positive vs. Negative) & $1.433(0.321-6.406)$ & 0.638 & N.A. & \\
\hline Cirrhosis (Positive vs. Negative) & $1.323(0.369-4.743)$ & 0.668 & N.A. & \\
\hline Child-Pugh grade (B vs. A) & $0.048(0.000-23944)$ & 0.700 & N.A. & \\
\hline $\operatorname{ALT}(>40 \mathrm{U} / \mathrm{L}$ vs. $\leq 40 \mathrm{U} / \mathrm{L})$ & $0.783(0.246-2.497)$ & 0.679 & N.A. & \\
\hline $\operatorname{AFP}(>400 \mathrm{ng} / \mathrm{ml}$ vs. $\leq 400 \mathrm{ng} / \mathrm{ml})$ & $2.258(0.756-6.743)$ & 0.145 & N.A. & \\
\hline Tumor number (multiple vs. one) & $3.570(0.998-12.896)$ & 0.052 & N.A. & \\
\hline Tumor size (>5 cm vs. $\leq 5 \mathrm{~cm})$ & $1.094(0.379-3.154)$ & 0.868 & N.A. & \\
\hline Tumor encapsulation (Yes vs. No) & $1.425(0.477-4.252)$ & 0.526 & N.A. & \\
\hline Satellite lesion (Yes vs. No) & $5.726(1.771-18.509)$ & 0.004 & $5.917(1.342-26.078)$ & 0.019 \\
\hline Vascular invasion (Yes vs. No) & $2.943(0.922-9.399)$ & 0.068 & N.A. & \\
\hline Edmondson classification (III-IV vs. I-II) & $1.057(0.354-3.155)$ & 0.921 & N.A. & \\
\hline $\mathrm{BCLC}$ stage $(\mathrm{B}+\mathrm{C}$ vs. $0+\mathrm{A})$ & $3.496(0.966-12.646)$ & 0.056 & N.A. & \\
\hline $\mathrm{EpCAM}^{+}$CTC $2^{-\Delta \Delta \mathrm{Cq}}(\geq 2.22$ vs. $<2.22)$ & $6.580(2.056-21.055)$ & 0.001 & $6.668(1.943-22.883)$ & 0.003 \\
\hline Treg/CD4 ${ }^{+}(\geq 5.07$ vs. $<5.07)$ & $2.993(0.998-8.947)$ & 0.045 & $0.825(0.196-3.468)$ & 0.792 \\
\hline
\end{tabular}

oncogenesis and tumor maintenance. There is sufficient evidence that a high ratio of tumor stem cell-like cells indicates a poor prognosis [21]. Sun et al. reported that EpCAM mRNA+ $C T C$ s retaining stem celllike characteristics are "high-quality seeds" for metastasis, and that the level of EpCAM mRNA+ CTCs is an ideal predictor for postoperative early recurrence and prognosis of HCC [22].

Tumor-related immune suppression is mediated mainly by increased TGF- $\beta$ secretion or direct Treg cell infiltration [23]. A recent study [24] found an association between intratumoral or peripheral blood Tregs and tumor invasion. Tregs mediate tumor immune escape and promote tumor growth mainly by suppressing tumor immune effector cells (especially cytotoxic lymphocytes), or by inducing effector $\mathrm{T}$ cell tolerance to tumor antigens. The resulting imbalance between intratumoral Tregs and cytotoxic $\mathrm{T}$ cells was shown to be an effective prognostic predictor. In our study, a significant correlation was observed between the levels of EpCAM ${ }^{\mathrm{mRNA}+} \mathrm{CTC}$ and peripheral Treg/CD4 ${ }^{+}$, with an increasing trend $(P=0.026)$. This result may supported that Tregs contributed as "soil" which may change the tumor microenvironment to help CTCs get out of immune clearance by cytotoxic $\mathrm{T}$ cells as well as colonization in $\mathrm{HCC}$ patients.

The results of univariate Cox analysis found that the significant prognostic factors for early recurrence included $E p C A M$ mRNA+ $C T C \geq 2.22(P=0.001)$ and Treg/CD $4+\geq 5.07(P=0.045)$. Further multivariate Cox analysis revealed $E p C A M^{\text {mRNA+ }} \mathrm{CTC} \geq 2.22(P=0.003$, $\mathrm{HR}=6.668)$ to be a significant and independent prognostic biomarker for early recurrence, in accordance with the study by Sun et al., which reported $E p C A M$ mRNA+ CTC $\geq 2$ to be an independent predictor for early $\mathrm{HCC}$ recurrence (within 1 year following resection) [13]. Survival curve analyses found that the early recurrence rates within the EpCAM mRNA+ CTC $\geq$ 2.22 group ( $12.5 \%$ vs. $58.8 \%, P=0.002$, Fig. 3a) and Treg/CD ${ }^{+} \geq 5.07$ group $(22.5 \%$ vs. $55.6 \%, P=0.038$, Fig. 3b) were markedly elevated. Combining these two factors of "soil" and "seeds", we found that the early recurrence rate in the group with combined high CTC and high Treg levels was significantly higher than in the combined low CTC and low Treg group (66.7\% vs. $10.3 \%, P<0.001$, Fig. $3 c$ ), while the recurrence rate within the combined high CTC and low Treg group was $46.4 \%$ higher than for the combined low CTC and low Treg group (50.0 \% vs. $10.3 \%, P=$ 0.004 , Fig. 3c). These results also implied that elevated Tregs cells could cause immune suppression, and contribute CTCs escape from peripheral immune clearance. Consequently, the spread of CTCs lead to $\mathrm{HCC}$ metastasis and recurrence. However, the mechanisms of EpCAM mRNA+ CTC and Treg cells interaction remain unclear, warranting future larger clinical studies as well as further basic explorative research.

The limitations of the current study were a small cohort size, short follow-up time, and only patients with 
a

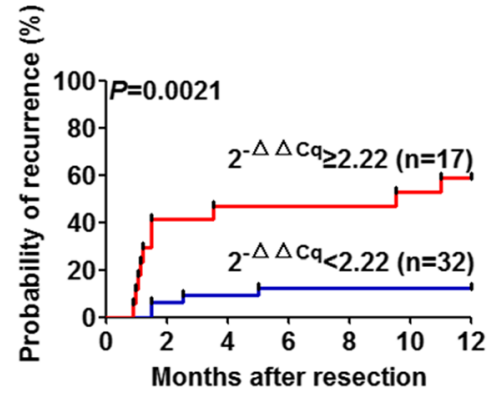

No. patients at risk

$\begin{array}{llllllll}\geq 2.22 & 17 & 10 & 9 & 9 & 9 & 8 & 7\end{array}$

$\begin{array}{llllllll}2.22 & 32 & 30 & 29 & 28 & 28 & 28 & 28\end{array}$

C

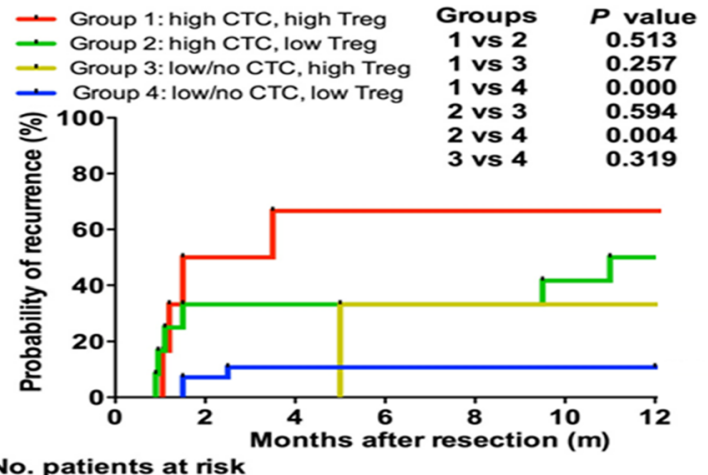

No. patients at risk

$\begin{array}{lccccccc}\text { Group 1 } & 6 & 3 & 2 & 2 & 2 & 2 & 2 \\ \text { Group 2 } & 11 & \mathbf{7} & \mathbf{7} & \mathbf{7} & \mathbf{7} & \mathbf{6} & \mathbf{5} \\ \text { Group 3 } & 3 & 3 & 3 & 2 & 2 & 2 & 2 \\ \text { Group 4 } & 29 & 27 & 26 & 26 & 26 & 26 & 26\end{array}$

Fig. $\mathbf{3}$ The Prognostic significance of EpCAM ${ }^{\text {mRNA+ }}$ CTC and Treg/CD4 ${ }^{+}$ratio in HCC patients. a. Kaplan-Meier analysis of HCC patients receiving curative resection treatment according to relative preoperative EpCAM expression $<2.22$ or $\geq 2.22\left(2_{q}^{-\Delta \Delta C}\right.$ algorithm transformation). b. Kaplan-Meier analysis of patients with HCC undergoing curative resection according to preoperative Treg/CD4+ $<5.07 \%$ or $\geq 5.07 \%$. c. Prognostic significance of combination of EpCAM ${ }^{\mathrm{mRNA+}} \mathrm{CTC}$ and Treg/CD4 $4^{+}$load with respect to time to recurrence in patients with high EpCAM ${ }^{\mathrm{mRNA+}} \mathrm{CTC}(\geq 2.22)$ and high Treg/CD4 ${ }^{+}(\geq 5.07 \%)$, high EpCAM ${ }^{\text {mRNA+ }} \mathrm{CTC}(<2.22)$ and low Treg/CD4 ${ }^{+}(<5.07 \%)$, low/no EpCAM ${ }^{\text {mRNA+ }}$ CTC $(<2.22)$ and high Treg/CD4 ${ }^{+}(\geq 5.07 \%)$, and low/no EpCAM ${ }^{\text {mRNA+ }}$ CTC $(<2.22)$ and low Treg/CD4 ${ }^{+}(<5.07 \%)$

Hepatitis-B induced HCC and early stages (BCLC 0 and A) have been included in this study, which may results the clinical significance of Edmondson classification and AFP in HCC were not be observed. These limitations will be addressed in our next step clinical investigation.

\section{Conclusions}

In summary, our study found an association between peripheral blood EpCAM ${ }^{\mathrm{mRNA}+} \mathrm{CTC}$ and $\mathrm{CD} 4^{+} \mathrm{CD} 25$ ${ }^{+} \mathrm{Foxp}^{+}$Treg preoperative levels with postoperative recurrence and metastasis in HCC patients. Combined measurement of both cell types may improve prognostic efficacy. We are currently carrying out a large prospective randomized controlled trial to further confirm the value of this combined measurement in predicting $\mathrm{HCC}$ recurrence and prognosis.

\section{Additional files}

Additional file 1: Table S1. Patient characteristics. (DOCX $16 \mathrm{~kb}$ ) Additional file 2: Figure S1. Flow cytometry analysis for Tregs. The original data of flow cytometry analysis for Tregs. (PNG 766 kb)

Additional file 3: Table S2. Association of lymphocyte subgroups with early recurrence. (DOCX $15 \mathrm{~kb}$ )

Abbreviations

CTCS, circulating tumor cells; HCC, hepatocellular carcinoma; Treg, T regulatory

Acknowledgments

We thank the Edanz Group China that made significant revision of the manuscript.

Funding

This study was supported by grants from the National High Technology Research and Development Program (863 Program) of China (2015AA020401), National Key Sci-Tech Project (2013ZX10002010-003, and 2013ZX10002011-004), the National Natural Science Foundation of China 
(81572064, 81530077, 81472676 and 81372317), the Projects from the Shanghai Science and Technology Commission (14DZ1940300, 14DZ1940302, 14411970200, 13140901900,134119a1201 and 14140902301), Specialized Research Fund for the Doctoral Program of Higher Education and Research Grants Council Earmarked Research Grants Joint Research Scheme (20130071140008) and the National Science \& Technology Pillar Program during the 12th Five-year Plan Period (2012BAl37B01), The funding plan for outstanding youth doctors training, Shanghai (2016-01)

\section{Availability of data and materials}

The raw data will not be shared. All potential findings based on row data analysis are presented in the manuscript or additional files.

\section{Authors' contributions}

Dr J F. and W G. had full access to all of the data in the study and take responsibility for the integrity of the data and the accuracy of the data analysis. Study concept and design: Y Z., BL W., W G., XR Y., J Z., J F. Acquisition of data: XR Y., J Z., J W., CY Z., Y Z., BL W. Analysis and interpretation of data: W G., XR Y., YW Z. Drafting the manuscript: W G., XR Y. Critical revision of the manuscript for import intellectual content: $Y Z_{\text {., }} J \mathrm{~F}$. Statistical analysis: W G., BL W, J W. Obtained funding: J F. Administrative, technical, and material support: J Z., J F. Study supervision: J F. All authors read and approved the final manuscript.

\section{Competing interests}

The authors declare that there are no competing interests.

\section{Consent for publication}

Not applicable.

\section{Ethics approval and consent to participate}

Approval for the use of human subjects was obtained from the Research Ethics Committee of Zhongshan Hospital, and informed consent was obtained from each individual enrolled in this study.

Received: 26 September 2015 Accepted: 6 July 2016

Published online: 20 July 2016

\section{References}

1. Bruix J, Sherman M. Management of hepatocellular carcinoma. Hepatology. 2005;42:1208-36

2. Izumi N. Prediction and prevention of intrahepatic recurrence of hepatocellular carcinoma. Hepatol Res. 2012;42:226-32.

3. Zhou L, Liu J, Luo F. Serum tumor markers for detection of hepatocellular carcinoma. World J Gastroenterol. 2006;12:1175-81.

4. Bruix J, Gores GJ, Mazzaferro V. Hepatocellular carcinoma: clinical frontiers and perspectives. Gut. 2014;63:844-55.

5. Friedlander TW, Premasekharan G, Paris PL. Looking back, to the future of circulating tumor cells. Pharmacol Ther. 2014;142:271-80.

6. Yamashita $T$, Honda M, Nakamoto $Y$, et al. Discrete nature of EpCAM+ and CD90+ cancer stem cells in human hepatocellular carcinoma. Hepatology. 2013;57:1484-97.

7. Preston CC, Maurer MJ, Oberg AL, Visscher DW, Kalli KR, Hartmann LC, et al. The ratios of CD8+ T cells to CD4+CD25+ FOXP3+ and FOXP3- T cells correlate with poor clinical outcome in human serous ovarian cancer. PLoS One. 2013;8:e80063.

8. Lin SZ, Chen KJ, Xu ZY, Chen H, Zhou L, Xie HY, Zheng SS. Prediction of recurrence and survival in hepatocellular carcinoma based on two Cox models mainly determined by FoxP3+ regulatory T cells. Cancer Prev Res (Phila). 2013;6:594-602

9. Guo W, Yang XR, Sun YF, Shen MN, Ma XL, Wu J, Zhang $C Y$, Zhou $Y, X u Y$, Hu B, Zhang $X$, Zhou J, Fan J. Clinical significance of EpCAM mRNA-positive circulating tumor cells in hepatocellular carcinoma by an optimized negative enrichment and qRT-PCR-based platform. Clin Cancer Res. 2014;20:4794-805.

10. Reinholz MM, Kitzmann KA, Tenner KS, Hillman DW, Dueck AC, Hobday TJ, Northfelt DW, Moreno-Aspitia A, Roy V, Laplant B, Allred JB, Stella PJ, Lingle W, Perez EA. Cytokeratin-19 and mammaglobin gene expression in circulating tumor cells from metastatic breast cancer patients enrolled in North Central Cancer Treatment Group trials, N0234/336/436/437. Clin Cancer Res. 2011;17:7183-93.
11. Yang XR, Xu Y, Shi GM, Fan J, Zhou J, Ji Y, Sun HC, Qiu SJ, Yu B, Gao Q, He YZ, Qin WZ, Chen RX, Yang GH, Wu B, Lu Q, Wu ZQ, Tang ZY. Cytokeratin 10 and cytokeratin 19: predictive markers for poor prognosis in hepatocellular carcinoma patients after curative resection. Clin Cancer Res. 2008;14:3850-9.

12. Llovet JM, Di Bisceglie AM, Bruix J, Kramer BS, Lencioni R, Zhu AX, Sherman M, Schwartz M, Lotze M, Talwalkar J, Gores GJ, Panel of Experts in HCCDesign Clinical Trials. Design and endpoints of clinical trials in hepatocellular carcinoma. J Natl Cancer Inst. 2008;100:698-711.

13. Yang XR, Xu Y, Yu B, Zhou J, Qiu SJ, Shi GM, Zhang BH, Wu WZ, Shi YH, Wu B, Yang GH, Ji Y, Fan J. High expression levels of putative hepatic stem/progenitor cell biomarkers related to tumour angiogenesis and poor prognosis of hepatocellular carcinoma. Gut. 2010;59:953-62.

14. Shah SA, Greig PD, Gallinger S, Cattral MS, Dixon E, Kim RD, Taylor BR, Grant $D R$, Vollmer CM. Factors associated with early recurrence after resection for hepatocellular carcinoma and outcomes. J Am Coll Surg. 2006;202:275-83.

15. Camp RL, Dolled-Filhart M, Rimm DL. X-tile: a new bio-informatics tool for biomarker assessment and outcome-based cut-point optimization. Clin Cancer Res. 2004;10:7252-9.

16. Yamamoto J, Kosuge T, Takayama T, Shimada K, Yamasaki S, Ozaki H, Yamaguchi N, Makuuchi M. Recurrence of hepatocellular carcinoma after surgery. Br J Surg. 1996;83:1219-22.

17. Budhu A, Forgues M, Ye QH, Jia HL, He P, Zanetti KA, Kammula US, Chen Y, Qin $L X$, Tang $Z Y$, Wang XW. Prediction of venous metastases recurrence and prognosis in hepatocellular carcinoma based on a unique immune response signature of the liver microenvironment. Cancer Cell. 2006;10:99-111.

18. Bjerkvig R, Tysnes BB, Aboody KS, Najbauer J, Terzis AJ. Opinion: the origin of the cancer stem cell: current controversies and new insights. Nat Rev Cancer. 2005;5:899-904.

19. Zou W. Regulatory T cells, tumour immunity and immunotherapy. Nat Rev Immunol. 2006;6:295-307.

20. Boman BM, Wicha MS. Cancer stem cells: a step toward the cure. J Clin Oncol. 2008;26:2795-9.

21. Pece S, Tosoni D, Confalonieri S, Mazzarol G, Vecchi M, Ronzoni S, Bernard L, Viale G, Pelicci PG, Di Fiore PP. Biological and molecular heterogeneity of breast cancers correlates with their cancer stem cell content. Cell. 2010;140:62-73.

22. Sun YF, Xu Y, Yang XR, Guo W, Zhang X, Qiu SJ, Shi RY, Hu B, Zhou J, Fan J. Circulating stem cell-like epithelial cell adhesion molecule-positive tumor cells indicate poor prognosis of hepatocellular carcinoma after curative resection. Hepatology. 2013;57:1458-68.

23. Heiber JF, Geiger TL. Context and location dependence of adaptive Foxp3+ regulatory $T$ cell formation during immunopathological conditions. Cell Immunol. 2012:279:60-5.

24. Gao Q, Qiu SJ, Fan J, Zhou J, Wang XY, Xiao YS, Xu Y, Li YW, Tang ZY. Intratumoral balance of regulatory and cytotoxic T cells is associated with prognosis of hepatocellular carcinoma after resection. J Clin Oncol. 2007;25: 2586-93.

\section{Submit your next manuscript to BioMed Central and we will help you at every step:}

- We accept pre-submission inquiries

- Our selector tool helps you to find the most relevant journal

- We provide round the clock customer support

- Convenient online submission

- Thorough peer review

- Inclusion in PubMed and all major indexing services

- Maximum visibility for your research

Submit your manuscript at www.biomedcentral.com/submit
) Biomed Central 